\title{
ARTICLE \\ Effect of Donor Funding on the Performance of Water Utilities in Kenya
}

\author{
Nicholas Daniel Otieno* Olanrewaju Isola Fatoki \\ Department of Accounting, Finance, and Economics, KCA University, Nairobi, Kenya
}

\section{ARTICLE INFO}

Article history

Received: 19 August 2021

Accepted: 8 September 2021

Published Online: 15 September 2021

Keywords:

Official development assistance

Water service providers

Kenya vision 2030

Sustainable development goals

Donor funding

\begin{abstract}
The objective of this study was to analyse the effect of donor funding on the performance of water utilities in Kenya. The study employed the use of a census by targeting all 88 regulated Water Services Providers (WSPs) in Kenya for a period of two years, 2016 and 2017. Data pertaining to the support received from the donors were obtained from the publications of the WSPs, Development Partners, Civil Society Organisations (CSOs), and Office of Auditor General (OAG). Performance data of the various WSPs were extracted from the Impact reports produced by Water Regulatory Board (WASREB), for the periods 2016/7 to 2017/8. Presentation of the data was done through the use of tables and charts with the application of SPSS. The study found that donor funding issued as Output Based Approach (OBA) leads to improved performance. This finding is expected to assist the Kenyan Government in negotiating for the Official Development Assistance (ODA) funding to be aligned to the government flagship projects under the Medium Term Plans (MTP). The study recommends OBA as the best way of issuing donor funding.
\end{abstract}

sources in the year 2012 compared to $76 \%$ in the year 1990. Government Spending Watch report, 2015, indicates that the Sub-Saharan Africa region never met this goal. The progress made on sanitation was low with 2.5 billion people not having access to improved sanitation facilities and 1 billion people still practicing open defecation. In September 2015, the world leaders adopted the Sustainable Development Goals (SDGs) which is aimed at ending poverty in all its form while ensuring that no one is left behind. SDG 6 aims to ensure availability and sustainable water and sanitation for all. According to the SDGs report 2018 of the Secretary-General, the progress of goal 6 indicated that in 2015, 29\% of the global population lacked safely managed drinking water supplies and 892 million people continued to practice open defecation. Though the

\footnotetext{
*Corresponding Author:

Nicholas Daniel Otieno,

Department of Accounting, Finance, and Economics, KCA University, Nairobi, Kenya;

Email:notieno.daniel@gmail.com
} 
proportion of the population practicing open defecation has reduced, the number of people without access to safe drinking water has increased compared to the WHO 2015 report on MDG key facts.

Owing to the importance placed on access to water, the donor community has supplemented the efforts of governments in enhancing access to water in developing countries ${ }^{[13]}$. Though this has been criticised as being undesirable ${ }^{[10]}$ within the context of the dependency theory, ${ }^{[8]}$ others have lauded it has been pivotal to solving Africa's water problems ${ }^{[13]}$. Regrettably, there is scanty literature on the nexus between donor funding and performance of water utilities in most parts of Africa. In Kenya for example, no documented study has examined the effect of donor funding on the performance of water utilities in Kenya. This happens in spite of the fact that donors fund over $70 \%$ of the water sector budget in developing countries ${ }^{[13]}$. This study thus seeks to bridge this literature gap. Literature also shows that often, donor aid, irrespective of its type, does not always yield the anticipated returns as posited by Beamon and Balcik ${ }^{[16]}$. This creates an interesting research lacuna since the success of water utility projects cannot be taken for granted. Literature also shows that the political context in which donor funded water utility projects are implemented also affects their success as shown by a study by Galvin and Habib in "the politics of decentralisation and donor funding in South Africa's Rural Water Sector." ${ }^{[17]}$. It is thus pertinent to study the sociopolitical determinants of the success of donor-funded projects in developing countries such as Kenya among others.

In Kenya, the Constitution of Kenya ${ }^{[3]}$ acknowledges that access to clean and safe water in adequate quantities is a basic human right as per article 43 (1) (d). The Water Act 2016 states that water functions are a shared responsibility between the national government and the county government ${ }^{[4]}$. The National government is mandated with policy formulation and regulation through the Ministry of Water and Sanitation and its sector institutions while water provision is the mandate of the County Government. The water sector in Kenya continues to experience a huge financial gap. According to the water regulator, (WASREB), to achieve the SDG $100 \%$ water coverage by 2030 , and to fill the current financial gap, the National Water Master Plan (NWMP) projects an investment of Ksh. 1.8 trillion, out of which 1.3 trillion will be required for water supply and the 500 billion will be required for sanitation. The Kenyan government projects to avail Ksh 592.4 billion for the duration of the National Water Master Plan ${ }^{[5]}$. This basically leaves the sector with a financial gap of over Ksh. 1 trillion. The Master plan further suggests that since the government budget available for the water supply subsector only covers $44 \%$ of the required investment cost, more private sector financing and Official Development Assistance funds being actively introduced in the sector could substantially reduce the financial gap.

Official Development Assistance (ODA) refers to government aid aimed to enhance the economic development and wellbeing of developing nations ${ }^{[6]}$. Such aid may be channelled through multilateral agencies such as the World Bank or Government bilateral cooperation. Developing countries are required to devote $0.7 \%$ of their gross national income to Official Development Assistance. The Organization of Economic Cooperation and Development maintains a list of developing countries entitled to be recipients of Official Development Assistance. The World Bank estimates that Development Partners contribute more than $50 \%$ to the Water Sector Budget by the year 2017. Good governance, pro-poor policy, capable and legitimate institutions with well-trained professionals, financing systems that are not susceptible to corruption, efficient and effective public financial management are important factors in providing access to water and sanitation for all ${ }^{[7]}$. It is on this basis that this study aimed to establish whether the Official Development Assistance funds had any effect on the performance of water sector utilities in Kenya. In accessing the performance of the water sector utilities the study checked on the Key Performance Indicators as outlined by the water regulator, Water Services Regulatory Board (WASREB).

Though access to clean and safe water in adequate quantity has been described as a basic human right ${ }^{[3]}$, only $60 \%$ of the population has access to safe water. Availability of fresh water in the world is diminishing owing to climate change and other human-related activities, and Kenya has been classified as a water-scarce country. Conflicts for the scarce water resource have emerged in various parts of the country and this has been attributed to a lack of legal framework for shared waters. Encroachment and destruction of key water catchment areas have further resulted in reduced water levels threatening the livelihoods of riparian's depending on these watercourses. The only accurate data available on water coverage are for the urban areas due to the lack of a cost-effective Information Technology system that is capable of capturing data across the country. The data for rural areas are therefore based on an estimate, which poses a huge risk in investment decision-making. For universal access to water to be achieved by the year 2030, more connections are required annually. Achieving Vision 2030 requires an investment of 100 billion, yet only 42 billion is disbursed to the sector for Water Supply and Sewerage Services development 
budget. Though the development of water infrastructure is the sole responsibility of the government, only $24 \%$ of the budgetary allocation is provided by the Government, while the remaining $76 \%$ is expected to be provided by donors. This poses a huge risk to the sustainability of the Water Infrastructure Projects since the donor funding is not assured, thus the need to innovate other funding sources. Since the Development Partners provide a significant proportion of the development budget related to the Water Supply Infrastructure, none of the studies has attempted to examine why only $60 \%$ of the population has access to safe water. In view of the background information above, this study aimed to determine the effect of donor funding on the performance of water utilities in Kenya. In views of this, the aim of this paper is to determine the effect of donor funding on the performance of water utilities in Kenya. The remaining part of the paper is divided into literature review, methodology, analysis and discussion of findings and conclusion and recommendation.

\section{Literature Review}

\subsection{Theoretical Review}

\section{Dependency Theory}

Paul Baran's dependency theory ${ }^{[8]}$, posits that development is only feasible if a country adopts a strategy of delinking and import substitution. The main characteristics of this theory entail, that international systems consist of dominant and dependent states; secondly, external forces influence the economic activity of dependent states, and; lastly, strong historical relationships between the two states reinforce the patterns of inequality. The theory asserts that aid leads to underdevelopment; increases inequality and conflict and; puts in place an authoritarian government. This theory views the world as either the core or the periphery. The core is the wealthy who are industrialised and educated while the peripheries possess mines, productive agricultural lands though they are the poor, illiterate, and powerless ${ }^{[9]}$. Dependency theorists classify the world into four different groups: Core of Core (CC); Periphery of Core (PC), and this is characterized by less global power and wealth than $\mathrm{CC}$ countries; Core of Periphery (CP), and these countries are wealthy though they are still developing and; Periphery of Periphery (PP), which entail the Least Developed Countries (LDC) ${ }^{[9]}$. Dependency theory is based on the fact that resources move from poor countries to rich countries. The poor countries export raw materials to rich countries, who in turn process the raw materials through a value addition chain. The poor countries in turn import these finished products at a more expensive price, causing inequality between the poor and rich states. Underdevelopment can only be overcome if countries delink from the core dominance.

Ekeh and Emeh ${ }^{[10]}$, through a paper on 'Dependency theory and Africa's underdevelopment: a paradigm shift from Pseudo-Intellectualism: The Nigerian Perspective', developed four main recommendations. First, the solution lies with Africans, therefore the political leaders and the private investors should stop complaining and instead brainstorm on the solutions. Secondly, the leaders of African countries should invest in their home countries and not in foreign bank accounts in countries that are considered to be tax havens, for example, Swiss. Thirdly, good governance needs to be practiced by every citizen of the various African states. The positive net effect of this is that it will put to an end ethnicity and the continent's greatest vice, corruption. Lastly, civil education needs to be promoted so that it can result in an intellectual revolution. This will bring to an end the political tension that arises during the election period, and thus the continent will once again become conducive for businesses.

Many scholars have always argued that the reason why Africa has remained to be poor is because of its over-reliance on aid. This has inhibited innovation and learning. Most of its resources have also continued to be exploited. This has led the African continent to continue being net exporters of raw materials. Industries have collapsed and this has led to further loss of jobs, increasing the poverty index of the continent. Lack of regulation has also led the continent to receive sub-standard products which are a health hazard to its citizens. If only the Paris Declaration on Aid effectiveness (OECD, 2005) could be followed, then the developing countries could have owned the projects under the support of donor agencies. Jackson, Nkwocha, and Boroh ${ }^{[11]}$ through their paper on 'Dependency and third world underdevelopment: Examining Production-Consumption Disarticulation in Nigeria', came up with five main recommendations.

First, for Africa to come out of the dependency syndrome, internal trade within the African Union states needs to be encouraged. The African Union states ratified the Africa Continental Free Trade Agreement (ACfTA) in 2018, though countries with big economies like Nigeria did not ratify the ACfTA ${ }^{[12]}$. Secondly, African countries need to diversify their revenue sources and not just rely on one source. Thirdly, industrialisation is required in Africa for it to detach itself from too much dependency on foreign aid. Kenya 2030 Vision footprint will in the short term, 2018-2022, focus on Manufacturing, Food security, Improved health care, and Housing, otherwise called the Big Four Agenda. Fourth, there should be an interlinkage of the various economic portfolios. For example, in 
Kenya, for the Big Four Agenda to be achieved, water is a cross-cutting issue that needs to be taken into consideration, since all these four Agendas will rely too much on water, and might, as a result, cause the country to experience water stress like the one experienced in South Africa in 2018. Lastly, for the continent to de-link itself from dependence on aid, rural development is key. The rural poor have always been ignored and as a result, this has led to rural-urban migration, leading to vices such as poor sanitation and increased crime rates. Quality education is hard to find in rural areas and drinking water quality is not befitting for any human standard. The system that has been developed to collect data to be used by the Water Services Regulatory Board is still not able to collect the rural data and thus this is always based on an approximation.

Ahiakpor studied the success and failure of the dependency theory in Ghana ${ }^{[13]}$. It found out that by concentrating too much on the past, the theory does not help so much in understanding the present. The government failed to anticipate the consequences of its initial actions because history is a poor predictor of the future. The fragility of democratic institutions complicates the problem of Least Developed Countries (LDCs) ability to evaluate the embedded hypothesis of the theory. Critics of the theory argue that the theory failed to argue the case of development experienced in East Asia. The theory also assumed that all the countries are the same and failed to appreciate the distinctiveness of the various developing countries. The theory only seemed to be applicable in the manufacturing sector and not in any other sector. This theory will assist us in examining the effect of grants on the performance of water utilities since approximately $70 \%$ of the water sector funding comes from development partners. Despite such a significant amount of funding coming from donors, the population with access to safe water has continued to remain low at $60 \%$. The theory will therefore assist in establishing whether the poor connectivity has been caused by reliance on the core dominance or foreign aid.

\subsection{Empirical Review}

This section will review empirical studies that have been carried out on the relationship between donor funding and water utility performance. It 1 review studies done on the impact of donor funding to the water utilities; the effect of technical assistance provided by donors to the utilities; the impact of newly introduced information systems by donors to the utilities; and the effect of governance on the performance of water utilities.

\section{Donor financing and performance of water utilities}

Few academic papers have been written on the effect of donor funding on the performance of water utilities. Reviewing this literature shows that while a significant amount of literature examines various aspects of donor funding, it tends to be fragmented. At present, no one has examined the effect of donor funding on the performance of water utilities in Kenya despite more than $70 \%$ of the sector budget coming from donors. This study seeks to address these gaps.

A publication by Ahsan and Gunawan analysed the cost and schedule performance of International Development Projects ${ }^{[14]}$. It aimed to find out the reasons why International Development projects to record a poor performance by analysing the cost and schedule performance. The sample population included 100 projects financed by the Asian Development Bank. The variables under study included project duration, schedule variation, and overall project performance. The study found out that only $13 \%$ of the projects are completed within schedule and budgeted cost. $73 \%$ of the projects start late and operate with less budgeted costs. The causes why International Development (ID) projects are always extended include long procurement procedures. Since ID projects rely too much on the services of a consultant, any delay in procuring the services of a consultant is likely to lead to poor performance of the implementing agency. The Government bureaucratic problems were found out to result in slow decision making. Most projects were found not to have utilized the planned budget and this was attributed to depreciation and devaluation of local currency and international competitive bidding. In Kenya, all the bilateral projects are required to present their project proposals with the Treasury. Before this happens there are always Government to Government negotiations to fulfill the Paris Declaration Agreement on Aid Effectiveness ${ }^{[15]}$, whereby the recipient of the donor funding should own the project. Mostly, these negotiations take relatively a very long time that inhibits the success of a given project. The donors are also under pressure to spend the money so that they can report back to their respective governments and thus sometimes more emphasis is laid towards spending the funds as compared to the actual delivery of quality output. The findings of this literature will offer great input to this study in laying an understanding of the factors that impact the effectiveness of donor funding. It also leads to the hypothesis $\left(\mathrm{HO}_{1}\right)$, there is no significant relationship between donor funding and the performance of Water Utilities in Kenya.

Beamon and Balcik undertook a study on performance measurement in humanitarian relief chains ${ }^{[16]}$. The objective of the study was to compare performance measurement in the humanitarian relief chain against the commercial supply chain and develop a performance 
metric for the humanitarian chain. The performance measurement analysis details were obtained through interviews. The finding of the study was in comparing the performance measurements between profit and non-profit organizations. It did this by checking on the revenue sources, goals, stakeholders, and performance measurement. The revenue sources of profit organizations were from the sale of the line products or services, while the non-profit organizations generated revenue from donor funding. The goal of the commercial entity was profit maximization while that of no-profit entity was to achieve a social purpose and mission. Commercial entities comprise homogenous stakeholders, for example, the directors of the entity while the non-profit entities comprise heterogeneous stakeholders including the government, donors, and the citizens to whom services are rendered to. The performance measurement for commercial entities is profit-based while it is difficult to establish a common performance measurement standard for non-profit entities. The challenges experienced in developing a performance measurement standard for commercial entities include the intangibility of the services offered, immeasurability of the missions, and unknown outcomes, and the variety of interest and standards. Performance measurement for relief entities is important in securing donor funding and improving the funding purpose. The Water Sector Regulatory Board developed key performance indicators to be used in assessing the performance of Water Service Providers. These included percentage of people with access to piped water, drinking water quality, Hours of uninterrupted water supply, Non-Revenue Water percentage, metering ratio, staff productivity per one thousand connections, Personnel expenditure as a percentage of operation and maintenance costs, Revenue Collection Efficiency, Operation, and Maintenance cost coverage ratio and finally percentage sewerage coverage. The donors should thus align their support activities towards these measurement indicators. The findings of this literature will assist the study in identifying the performance measurement standard of donor-funded projects. This leads to the hypothesis $\left(\mathrm{HO}_{2}\right)$; donor-funded water utility projects do not significantly align to the various performance measurement indicators.

Galvin and Habib studied the politics of decentralisation and donor funding in South Africa's Rural Water Sector ${ }^{[17]}$. It examined the impact of decentralisation policies supported by donors in regard to its implementation. Primary data were obtained by interviewing 47 Government, Donor, and NGO Officials. The study found out that in practice donors promote a state-centric decentralisation while they claim to promote a community-centric decentralisation. This reinforces the institutional bias of the Government. The study found out that donor funding is used to support initiatives of the South African Government. The donors who provide funding and technical assistance to the South African Government, therefore, reinforce institutional balance by indirectly promoting the state-centric decentralisation. Some stakeholders were of the opinion that despite donors spending millions of rands, there was no significant impact on the outcome. The study further noted that the capacity of the government employees was enhanced through the training offered. The effects of a state-centric decentralisation system should be of great concern to the development partners since it does not promote community participation thus hampering efficient delivery of services. The findings of this paper will assist us in establishing the best practices in which donor funding can be expended.

\section{Methodology}

The study applied a longitudinal descriptive research design. This is because the sample used was fixed and large. It also enabled the study to determine the degree to which the variables were related. The research focused on the $88 \mathrm{WSPs}^{[18]}$ regulated by the WASREB. Since the population under study comprises $88 \mathrm{WSPs}$, the research will not sample the population. It, therefore, applied census, since the population is small. Secondary data were collected from the WASREB Impact publications for the period 2016 to 2017. The research got additional data from the OECD website, MTEF of the Government of Kenya, WSTF ${ }^{[19]}$, WASPA publications ${ }^{[20]}$, and Audit reports from the Office of the Auditor-General. The panel data comprised 176 observations since 88 WSPs were analysed over a period of 2 years. The study adopted the use of panel data analysis. This is because the interest of the study was to analyse the effect of the variables over a specified period. SPSS software was used for the analysis. In examining the effect of donor funding on the performance of water utilities, the research adopted the simple panel data regression econometric model as applied by Waweru and Fatoki ${ }^{[21]}$.

Where,

$\mathrm{Y}=$ the dependent variable (Water Utilities Performance)

$\mathrm{I}=$ Number of observations ( $88 \mathrm{WSPs})$

$\mathrm{T}=$ Time period for the study ( 2 years)

$\beta_{0}=$ Regression coefficient

$\mathrm{X}_{1}=$ Donor funding

Water utilities performance was measured by assessing the coverage ratio, Non-Revenue Water (NRW) and revenue collection efficiency. On its part, donor funding was measured by the amount of money received in Kenya 
shillings.

\section{Results and Analysis}

\subsection{Descriptive Statistics}

Descriptive statistics give an initial indication of variables that can be used in regression analysis giving several summarized statistics on a variable, e.g. mean, standard deviation, and also often the lowest and highest observation.

Table 1. Descriptive Statistics

\begin{tabular}{|c|c|c|c|c|c|}
\hline & N & Minimum & Maximum & Mean & $\begin{array}{c}\text { Std. } \\
\text { Deviation }\end{array}$ \\
\hline $\begin{array}{c}2016 \text { Coverage } \\
\text { ratio }\end{array}$ & 76 & 3.00 & 96.00 & 52.34 & 25.56 \\
\hline $\begin{array}{c}2017 \text { Coverage } \\
\text { ratio }\end{array}$ & 85 & 2.00 & 99.00 & 53.22 & 25.24 \\
\hline $\begin{array}{c}2016 \text { NRW } \\
2017 \text { NRW }\end{array}$ & 71 & 18.00 & 83.00 & 46.33 & 13.70 \\
\hline $\begin{array}{c}2016 \text { Rev. } \\
\text { Collect } \\
\text { Efficiency }\end{array}$ & 76 & 38.00 & 114.00 & 90.26 & 13.46 \\
\hline $\begin{array}{c}2017 \text { Rev. } \\
\text { Collect } \\
\text { Efficiency }\end{array}$ & 80 & 55.00 & 126.00 & 94.35 & 12.76 \\
\hline $\begin{array}{c}\text { Donor Funding } \\
\text { Ding }\end{array}$ & 16 & 483, & 289,406, & 78,264, & 87,431, \\
\hline
\end{tabular}

The descriptive statistics in Table 1 show the total number of data analysed (n) which represents the WSPs regulated by the WASREB in Kenya. According to Gujarati (2003), the standard deviation represents a measure of the dispersion from the mean which indicates the smaller the standard deviation the more accurate future predictions maybe because there is less variability. In Table 1, the results indicate that Water utility performance, Information systems, Technical Assistance, Donor Funding do deviate to some extent from the mean although the variables have smaller standard deviations thus more accurate the future predictions. The mean coverage ratio in 2016 and 2017 was 52.34 and 53.22 with a standard deviation of 25.56 and 25.24 respectively, meaning that the data is clustered around the mean. The mean for NRW in 2016 and 2017 was 46.33 and 45.48 with a standard deviation of 13.70 and 12.64 respectively. Revenue collection efficiency has a mean of 90.26 in 2016 and 94.35 in 2017 and a standard deviation of 13.46 in 2016 and 12.76 in 2017. Donor funding has a mean of 78,264,589.29. Technical assistance has a mean of 9,940 , and 7841.16 .

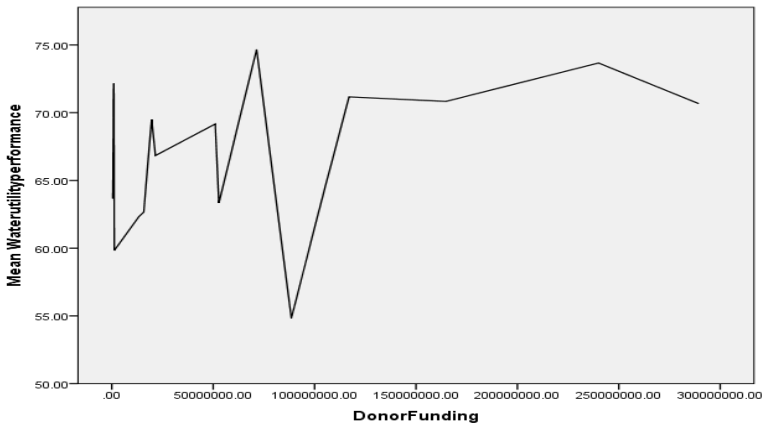

Figure 1. Trend Analysis for Donor Funding

\subsection{Donor Funding}

Donor funding has a positive effect on the performance of Water Service Providers in Kenya. A unit increase in donor funding issued directly to the WSPs will lead to a 2.116 increase in the performance of the Water Service Providers. The measures of performance considered under this study were the population of people with access to piped water, the revenue collection efficiency, and the percentage of Non-Revenue Water. All these measures of performance data were retrieved from the impact reports produced by the Water Sector Regulatory Board. The donor funding disbursed in cash to the Water Service Providers through the Output-Based Funding (OBF) Programme of the Water Sector Trust Fund has been found to have a greater impact on the performance of WSPs. OBF refers to where the donors give the money to the WSTF, which issues the cash to the WSPs through various calls. The WSTF enters into an arrangement with the commercial banks, who lend the funds to the WSPs and the donors act as bank guarantors just in case the WSPs don't honour their obligation of paying the loans. The WSPs will in turn be given a subsidy of up to $60 \%$ by the WSTF. This subsidy is the donor funding issued to the WSTF. The study findings indicate that OBA increases ownership and accountability. With good policies in place, the WSPs are able to make decisions and investments that improve the coverage ratio, reduce Non-Revenue Water, and improve revenue collection efficiency. Galvin and Habib ${ }^{[17]}$ studied the politics of decentralisation and donor funding in South Africa's Rural Water Sector. It found out that the state-centric decentralisation system failed to promote community participation thus hampering efficient delivery of services. This study finding however introduces a new dimension to the findings by Galvin and Habid ${ }^{[17]}$, whereby it is not the role of the donors to ensure community participation but instead the partner Government should be the one taking the lead role in ensuring proper public participation as enshrined in our constitution ${ }^{[6]}$. 


\subsection{Correlation}

The analysis was carried out using the Standard Package of Statistical Science (SPSS) to determine the correlation Pearson Product Moment Correlation was used. The summary of the correlations is shown in the table below:

Table 2. Test of Correlations

\begin{tabular}{|c|c|c|c|}
\hline & & WUP & $\mathrm{DF}$ \\
\hline \multirow{3}{*}{ WUP } & Pearson Correlation & 1 & \\
\hline & Sig. (2-tailed) & & \\
\hline & $\mathrm{N}$ & 86 & \\
\hline \multirow{3}{*}{ DF } & Pearson Correlation & .410 & 1 \\
\hline & Sig. (2-tailed) & .115 & \\
\hline & $\mathrm{N}$ & 16 & 16 \\
\hline
\end{tabular}

The data presented in the table above on the effect of donor funding (DF) on Water Utilities performance (WUP) in Kenya were computed into single variables per factor by obtaining the averages of each factor. Pearson's correlations analysis was then conducted at $95 \%$ confidence interval and 5\% confidence level 2-tailed. The table indicates that DF did not have a significant effect on WUP as shown by insignificant $p$-value ( $p>0.05$ ) at a $95 \%$ confidence level. In this regard, all the two null hypotheses namely $\mathrm{H}_{\mathrm{O} 1}$ : there is no significant relationship between donor funding and the performance of Water Utilities in Kenya and $\left(\mathrm{H}_{\mathrm{O} 2}\right.$ : donor-funded water utility projects do not significantly align to the various performance measurement indicators were accepted.

\subsection{Diagnostic Tests}

Prior to carrying out regression analysis, diagnostic tests were carried out. These included linearity and multicollinearity tests.

\subsubsection{Linearity Test}

Linearity means the correlation variables, which is represented by a straight line. Linearity test aims to determine the relationship between independent variables and the dependent variables is linear or not. If the value sig, deviation from linearity $>0.05$ then the relationship be- tween the independent variable and the dependent variable are linearly dependent. If the Value sig. deviation from linearity $<0.05$ then the relationship between independent variables with the dependent is not linear.

Table 3 results indicate that value of sig deviation from the linearity of donor funding was $>0.05$ and it can therefore be concluded that there is a linear relationship between the donor funding and the performance of Water Utilities in Kenya.

Table 3. Test of Linearity

\begin{tabular}{|c|c|c|c|c|c|c|c|}
\hline & & & $\begin{array}{l}\text { Sum of } \\
\text { Squares }\end{array}$ & $\mathrm{df}$ & $\begin{array}{l}\text { Mean } \\
\text { Square }\end{array}$ & $\mathrm{F}$ & Sig. \\
\hline \multirow{5}{*}{$\begin{array}{l}\text { Water utility } \\
\text { performance } \\
\text { * Donor } \\
\text { Funding }\end{array}$} & \multirow{3}{*}{$\begin{array}{c}\text { Between } \\
\text { Groups }\end{array}$} & (Combined) & 145.256 & 6 & 24.209 & .189 & .979 \\
\hline & & Linearity & 14.466 & 1 & 14.466 & .113 & .738 \\
\hline & & $\begin{array}{c}\text { Deviation from } \\
\text { Linearity }\end{array}$ & 130.790 & 5 & 26.158 & .204 & .960 \\
\hline & \multicolumn{2}{|c|}{ Within Groups } & 10142.962 & 79 & 128.392 & & \\
\hline & \multicolumn{2}{|r|}{ Total } & 10288.218 & 85 & & & \\
\hline
\end{tabular}

\subsubsection{Multicollinearity}

Multicollinearity is a test that evaluates whether the independent variables are highly correlated. The primary concern is that as the degree of Multicollinearity increases, the regression model estimates of the coefficients become unstable and the standard errors for the coefficients can get wildly inflated. The variance inflation factor (VIF) was used to evaluate the level of correlation between variables and to estimate how much the variance of a coefficient was inflated because of linear dependence with other predictors. As a rule of thumb if any of the VIF are greater than 10 (greater than 5 when conservative) then there is a probability of a problem with Multicollinearity and is harmful to the study ${ }^{[23]}$. Tolerance, defined as $1 / \mathrm{VIF}$, is used by many researchers to check on the degree of collinearity. A tolerance value lower than 0.1 is comparable to a VIF of 10. It means that the variable could be considered as a linear combination of other independent variables ${ }^{[23]}$. The results for tests of Multicollinearity were as presented in Table 4.

Based on the coefficients output, collinearity statistics obtained VIF value of donor funding $=1.27$. This means that the VIF value obtained is greater than 1 and less than 10. It can be concluded that there is no multicollinearity.

Table 4. Test of Multicollinearity

\begin{tabular}{|c|c|c|c|c|c|c|c|c|}
\hline & \multirow{2}{*}{ Model } & \multicolumn{2}{|c|}{ Unstandardized Coefficients } & \multirow{2}{*}{$\begin{array}{c}\begin{array}{c}\text { Standardized } \\
\text { Coefficients }\end{array} \\
\text { Beta } \\
\end{array}$} & \multirow{2}{*}{$\mathrm{t}$} & \multirow{2}{*}{ Sig. } & \multicolumn{2}{|c|}{ Collinearity Statistics } \\
\hline & & B & Std. Error & & & & Tolerance & VIF \\
\hline \multirow{2}{*}{1} & (Constant) & 70.354 & 9.533 & & 7.380 & .000 & & \\
\hline & Donor Funding & $1.747 \mathrm{E}-008$ & .000 & .274 & .878 & .403 & .785 & 1.274 \\
\hline
\end{tabular}


Table 5. Regression Results Without the Moderating Variable

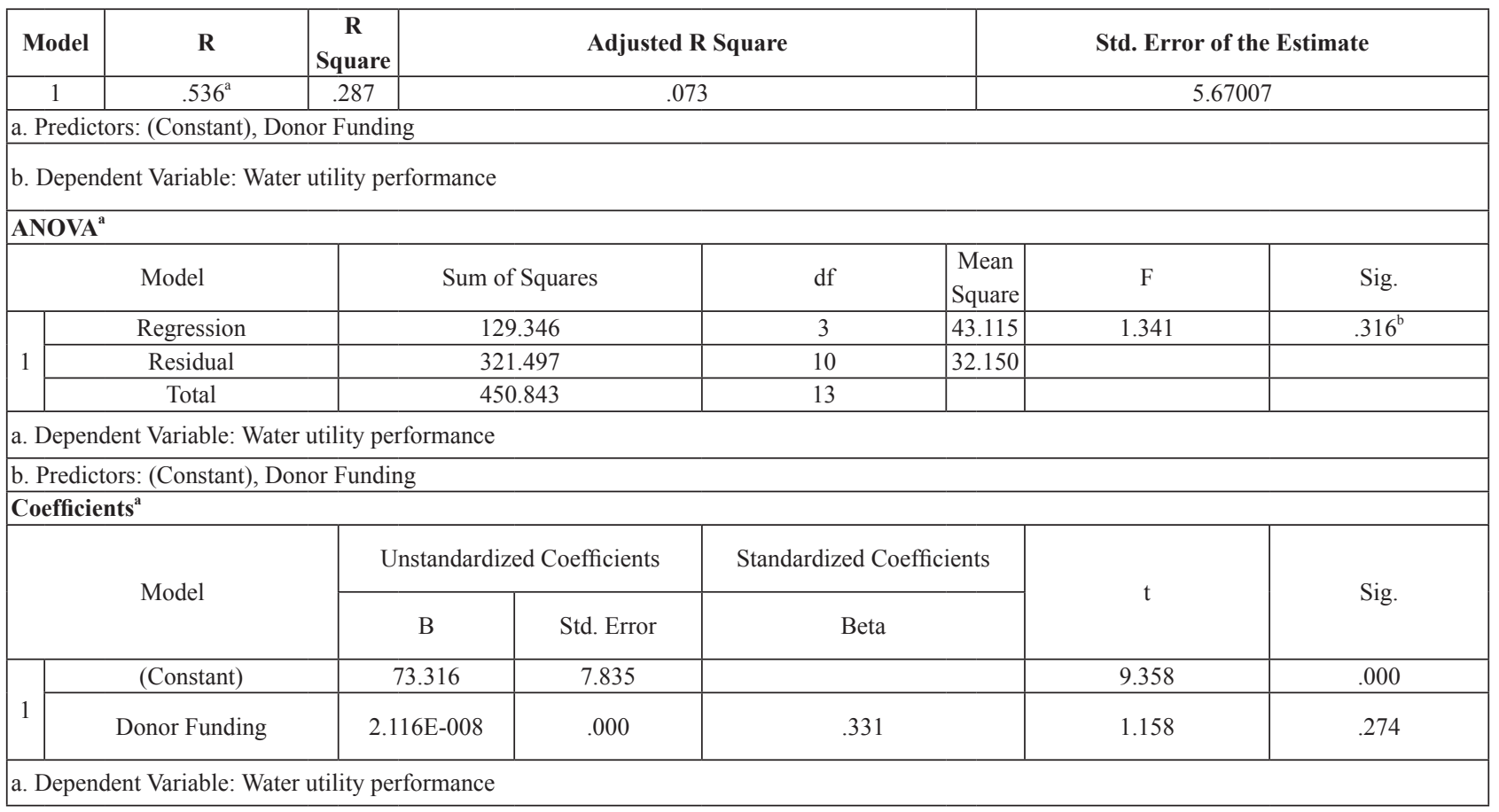

Table 6. Regression Results with the Moderating Variable

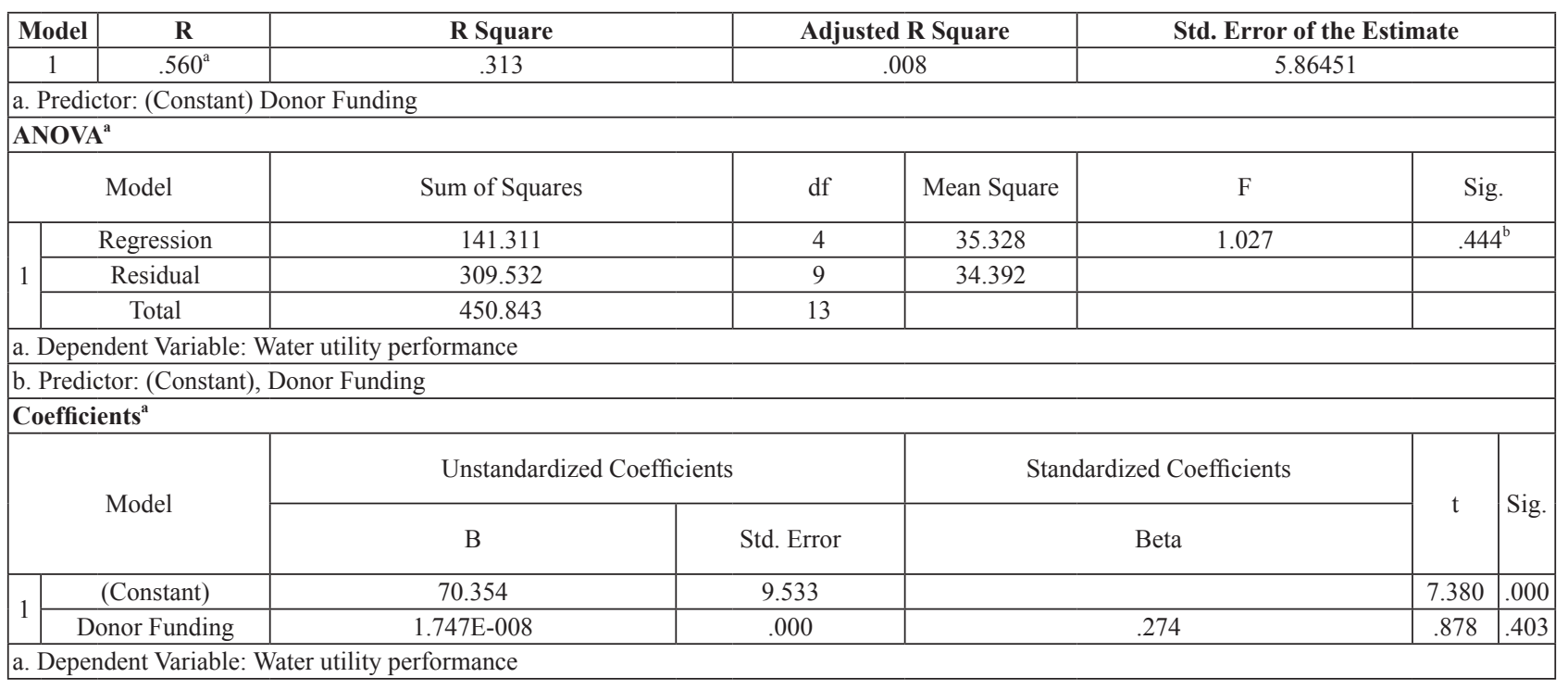

\subsection{Regression}

This section presents the results after performing a multiple regression analysis. Regression analysis is a set of statistical processes for estimating the relationships among variables.

The results presented in Table 5 above indicate that the effect of donor funding on the performance of Water Utilities in Kenya was not significant $(\mathrm{R}$ Square $=0.287, \mathrm{~F}=$ $1.341, \mathrm{p}>0.05)$. The test results indicated that $28.7 \%$ of the variation in performance of Water Utilities in Kenya could be explained by variation in donor funding which was not significant $(\mathrm{p}>0.05)$. The coefficients resulting from the regression model in Table 5 show that holding Donor Funding constant as zero, Water utility performance in Kenya will be 73.316. A unit increase in donor funding will lead to a 2.116E-008 units increase in Water utility performance in Kenya. These findings further buttress the findings from correlation analysis where the two null hypotheses were rejected.

The results presented in Table 6 above indicate that the effect of donor funding together with the moderating var- 
iable of governance on the performance of Water Utilities in Kenya was also not significant ( $\mathrm{R}$ Square $=0.313, \mathrm{~F}=$ $1.027, \mathrm{p}>0.05)$. The test results indicated that $31.3 \%$ of variation in performance of Water Utilities in Kenya could be explained by variation in donor funding, which was not significant $(p>0.05)$. The coefficients results from the regression model in table 6 further shows that Donor Funding constant as zero, Water utility performance in Kenya will be 70.354 .

\section{Conclusions and Recommendations}

The study found out that donor funding issued directly to WSPs has a positive effect on the performance of the WSPs. This study confirms the agreement of the Paris Declaration on Aid Effectiveness whereby it was stated that for aid to be effective, the receiver of the funds should own the project. If the WSPs are given the liberty to implement the projects on their own without the interference of the external parties and given that they uphold high standards of integrity, then this will lead to improved performance of the WSPs. The donors should therefore align their support along with that of the WSPs and not the other way round. The means of disbursing the funds should also change whereby WSPs should be given the money for project implementation. The Output-Based Approach should be promoted as a means by which the donors can support the WSPs.

The study recommends that Output-Based Aid should be adopted as a means of disbursing donor funding to the WSPs. This is because WSPs remain accountable for meeting the objective of the funding before getting a subsidy from the donors. This ensures ownership of the implemented projects by the WSPs.

\section{References}

[1] United Nations. (2015). Transforming Our World: The 2030 Agenda for Sustainable Development. New York: UN Publishing.

[2] WHO. (2018). Fact Sheets: Millennium Development Goals (MDGs). World Health Organization. https:// www.who.int/news-room/fact-sheets/detail/millennium-development-goals-(MDGs)

[3] Government of Kenya. (2010). The Constitution of Kenya. Nairobi: Government Printer.

[4] Government of Kenya. (2016). Water Act, 2016 (No. 43 of 2016). Nairobi: Government Printer.

[5] WASREB (2018). A Performance Report of Kenya's Water Services Sector 2015/16 and 2016/17. Impact Issue No. 10.

[6] OECD (2018). Development Co-operation Report
2018: Joining forces to leave no one behind. Secretary-General of the OECD Report, Paris.

[7] GIZ. (2019). "Access to Water and Sanitation in Sub-Saharan Africa." Briefing Document. GIZ. https:// www.oecd.org/water/GIZ_2018_Access_Study_ Part\%20II_Narrative\%20Report_Briefing_document. pdf.

[8] Baran, P. (1957).The political economy of growth. New York: Monthly Review Press.

[9] Romaniuk, S.N. (2017). Dependency Theory. In: P. Joseph, ed. The SAGE Encyclopedia of War: Social Science Perspectives. Thousand Oaks: SAGE.

[10] Ekeh, J., \& Emeh, E. (2013). Dependency Theory and Africa's Underdevelopment: A paradigm shift from Pseudo-Intellectualism (The Nigerian Perspective). In International Journal of African and Asian Studies. 1, 116-128.

[11] Jackson, J., Nkwocha, I., \& Boroh, S. (2016). Dependency and Third World Underdevelopment: Examining Production-Consumption Disarticulation in Nigeria. African Research Review, 10(5), 44.

DOI: http://dx.doi.org/10.4314/afrrev.v10i4.15.

[12] World Bank. (2020). The African Continental Free Trade Area: Economic and Distributional Effects. Washington, DC: World Bank.

[13] Ahiakpor, J. (1985). The success and failure of dependency theory: the experience of Ghana. International Organization, Cambridge University Press, 39(3), 535-552.

[14] Ahsan, K., \& Gunawan, I. (2010). Analysis of cost and schedule performance of international development projects. International Journal of Project Management, 28(1), 68-78.

[15] OECD. (2005). The Paris Declaration on Aid Effectiveness. OECD. March 2, 2005.

[16] Beamon, B., \& Balcik, B. (2008). Performance measure in humanitarian relief chains. International Journal of Public Sector Management, 21 (1), 4-25. 10.1108/09513550810846087.

[17] Galvin, M., \& Habib, A., (2003). The Politics of Decentralisation and Donor Funding in South Africa's Rural Water Sector. Journal of Southern African Studies, 29(4), 865-84.

[18] WSP (2004). Sector Finance and Resource Flows for water supply: A pilot application for Kenya. Executive summary, sector financing papers.

[19] WSTF (2018). Result Based Financing for Water Services Providers in Kenya. Water Fund financing the Water Sector. WSTF.

[20] WASPA (2018). Advocating for Quality Water Services: Strategic Plan 2018-2022. Supported by SNV. 
[21] Waweru, P., \& Fatoki, O. I. (2021). GDP-Indexed bond and budget financing options in Kenya. International Journal of Innovative Research in Accounting and Sustainability (IJRAS/AAUA) 6(1), 221-248. https://ijiras.org.

[22] Gujarati, D. N. (2013). Basic econometrics, (5th ed.).
New York: The McGraw-Hill Companies.

[23] Newbert, S. (2008). Value, Rareness, Competitive Advantage and Performance: A Conceptual-Level Empirical Investigation of the Resourced-Based View of the Firm. Strategic Management Journal, 29 (1), 745-768. https://doi.org/10.1002/smj.686. 